\title{
Localization and Active Transport of mRNA in Axons of Sympathetic Neurons in Culture
}

\author{
Marguerite Olink-Coux and Peter J. Hollenbeck \\ Department of Neurobiology, Harvard Medical School, Boston, Massachusetts 02115
}

In neurons, the establishment and maintenance of distinct somatic, dendritic, and axonal domains has long been known to rely on regulated traffic of organelles and proteins. More recently, the local targeting of specific mRNAs has also been demonstrated, at least in dendrites, to provide a local supply of specific proteins. Here we set out to test directly for the presence of mRNA in axons of cultured chick sympathetic neurons, to examine their distribution during axonal outgrowth, to determine the reliance of this distribution on specific cytoskeletal elements, and to assess whether the axonal and somatic mRNA complements differ. Using fluorescent in situ hybridization, we found that sympathetic axons do contain poly $\left(A^{+}\right)$ $m R N A$ along their length in a pattern that changes gradually as axons elongate, from an evenly dispersed punctate distribution with strong growth cone staining to a distribution focused at branch points, varicosities, and some growth cones. Selective perturbations of the cytoskeleton revealed that the presence of axonal mRNA was dependent on microtubules (MTs), but not actin filaments, indicating that mRNA transport and/or anchoring within the axon are active processes involving MTs. Finally, reverse transcription-PCR amplification of RNAs from the axonal and somatic compartments showed that $\beta$-actin mRNA was present in both compartments, whereas mRNA encoding $\alpha$-tubulin was restricted to the somatic compartment and entirely absent from the axons. Thus, the mRNA populations in the soma versus the axon are both quantitatively and qualitatively different, and these neurons are able to direct specific mRNAs to the axon.

Key words: axon; axonal transport; mRNA; microtubules; microfilaments; in situ hybridization; RT-PCR
An essential aspect of molecular trafficking is the sorting, selective transport, and regional docking of mRNA molecules in cytoplasmic microdomains distant from the nucleus (for review, see Wilhelm and Vale, 1993; Rings et al., 1994; St. Johnston, 1995). Localized mRNAs play essential roles in early development in Xenopus (Melton, 1987; Kloc et al., 1991; Elinson et al., 1993; Ku and Melton, 1993; Mosquera et al., 1993; Kloc and Etkin, 1994) and Drosophila (Berleth et al., 1988; Ephrussi et al., 1991; Wang and Lehman, 1991; Gavis and Lehman, 1992; Neuman-Silberberg and Schubach, 1993) (for review, see Ding and Lipshitz, 1993). Specific mRNA localization has also been reported in muscle (Merlie and Sanes, 1985; Fontaine et al., 1988; Fontaine and Changeux, 1989; Cripe et al., 1993; Morris and Fulton, 1994), fibroblasts and myoblasts (Hill and Gunning, 1993; Kislauskis et al., 1993), oligodendrocytes (Ainger et al., 1993), epithelia (Hoock et al., 1991), and neurons (Garner et al., 1988; Bruckenstein et al., 1990; Burgin et al., 1990; Kleiman et al., 1990; Lyford et al., 1995) (for review, see Steward and Banker, 1992). Although the mechanisms of mRNA sorting and transport are not well understood, mRNA localization before translation can serve as an efficient mechanism to distribute proteins within the cell, and may allow for timely regulation of protein synthesis in response to local

\footnotetext{
Received Aug. 4, 1995; revised Nov. 2, 1995; accepted Nov. 21, 1995.

This work was supported by Grant NS27073 from National Institutes of Health (P.J.H.) and by the Harvard Mahoney Neuroscience Institute (M.O.-C.). We thank the following people: Marina Chicurel, Gabriel Corfas, and particularly Gary Basscll for invaluable help in developing the in situ hybridization procedures; Marina Chicurel, Christopher DeFranco, Jim Deshler, and Raul Krauss for advice on RT-PCR techniques; Myrta Otero and Rose Weld for technical assistance; and Robert Morris, Kelly Overly, Heather Rieff, Kathleen Buckley, and Kyung-Dall Lee for helpful discussions and critical reading of this manuscript.

Correspondence should be addressed to Peter J. Hollenbeck, Department of Neurobiology, Harvard Medical School, 220 Longwood Avenue, Boston MA 02115. Copyright $(1996$ Socicty for Neuroscience $0270-6474 / 96 / 161.346-13 \$ 05.00 / 0$
}

stimuli. In addition, the role of the cytoskeleton in mRNA transport and in the anchorage of most cellular mRNA is established in several systems (for review, see Hesketh and Pryme, 1991; Pachter, 1992; Suprenant, 1993).

Neurons seem to be a likely cell type to use mRNA transport and localization, because their functional and morphological polarization can place a majority of their axonal cytoplasm at a considerable distance from the nucleus, Golgi, and rough endoplasmic reticulum. However, at least in vertebrate neurons that have a distinct and highly elongated axonal compartment, transport along the axon of material synthesized in the soma has long been considered adequate to support axonal growth and maintenance. In addition, conventional ultrastructural methods generally have revealed a paucity of ribosomes in axoplasm (Peters et al., 1976). Thus, there has been little perceived need to invoke local translation in the axon, and axonal transport studies have lead to the conclusion that, at least in vertebrates, the axonal compartment is devoid of synthetic capacity (for review, see Grafstein and Forman, 1980). As a result, analyses of the targeting of neuronal mRNAs have focused primarily on the somatodendritic compartment (for review, see Steward and Banker, 1992; Steward, 1994). However, evidence has gradually accumulated favoring the idea that axonal mRNA localization may also be an important feature of the cell biology of neurons (for review, see Mohr and Richter, 1993; Van Minnen, 1994b). Three invertebrate systems show unambiguously the presence of axonal mRNAs, translation machinery, and/or evidence of autonomous protein synthesis (Rapallino et al., 1988; Giuditta et al., 1991; Davis et al., 1992; Kaplan et al., 1992; Crispino et al., 1993a,b; Gioio et al., 1994; Van Minnen, 1994a). In addition, in one vertebrate system, the neuroendocrine cells of the hypothalamo-hypophyseal tract, the presence and transport of axonal mRNAs has been described (Jirikowski et al., 
1990; Mohr et al., 1991; Mohr and Richter, 1992; Skutella et al., 1994; Trembleau et al., 1994). Olfactory sensory neurons are the only other example in vertebrates in which specific transcripts have been detected in the axons and terminals (Ehrlich et al., 1990; Ressler et al., 1994; Vassar et al., 1994; Wensley et al., 1995). However, these studies seem not to have shaken the dogma that the supply of axonal proteins relies entirely on anterograde transport of material synthesized in the soma (Vale et al., 1992; Alberts et al., 1994). This could be attributable to their analysis of large invertebrate axons or atypical vertebrate axons the cell biology of which is considered to have unique cytotypic features.

In the present study, we probed for axonal mRNAs in vertebrate neurons having a distinct, extended axonal compartment, determined the distribution of axonal mRNAs during axonal outgrowth and its reliance on cytoskeletal elements, and assessed whether the axonal and somatic mRNA complements were identical. We used chick sympathetic neurons grown under culture conditions in which they elaborate axons but not dendrites (Baas and Ahmad, 1992, 1993). To assess whether growing axons contained mRNA, we used two techniques in parallel: in situ hybridization of cultured neurons with probes for polyadenylated mRNAs [poly $\left(\mathrm{A}^{+}\right)$mRNAs], and reverse transcription (R' $\left.\mathrm{T}^{\prime}\right)-\mathrm{PCR}$ amplification of axonal versus somatic mRNA. Our data indicate that these axons do contain poly $\left(\mathrm{A}^{+}\right)$mRNAs distributed in a pattern that changes through their development, and that the axonal and somatic mRNA complements differ. Furthermore, selective perturbation of the axonal cytoskeleton showed that the localization of poly $\left(\mathrm{A}^{+}\right)$mRNAs in axons requires microtubules (MTs), but not microfilaments (MFs), and that it relies on active transport.

\section{MATERIALS AND METHODS}

\section{Materials}

All reagents, tissue culture media, and supplements were obtained from Sigma (St. Louis, MO) unless specified otherwise. Tissue culture plastic was obtained from Dow Corning (Corning, NY). Monoclonal rat anti-tubulin YL1 was a gift from J. Kilmartin (Kilmartin, 1982). Mouse nerve growth factor (2.5S), digoxigenin-11-deoxyuridine triphosphate (digoxigenin-11dUTP), digoxigenin detection kits, digoxigeninconjugated sheep anti-horseradish peroxidase (HRP), 5S RNA, T4 polynucleotide kinase, and in situ blocking reagent were obtained from Boehringer Mannheim (Indianapolis, IN). All other secondary antibodies were from Vector Laboratories (Burlingame, CA), except Cy3conjugated rabbit anti-digoxigenin (Jackson Immunoresearch, West Grove, PA). Rhodamine-phalloidin was obtained from Molecular Probes (Eugene, OR). Acetylated bovine serum albumin (BSA) and deoxynucleoside triphosphates (dNTPs) were obtained from Stratagene (La Jolla, CA). AmpliTaq DNA polymerase, AmpliWax PCR Gem50 and oligo $\left(\mathrm{dT}_{16}\right)$ were obtained from Perkin-Elmer (Foster City, CA). Ribonuclease inhibitors and Moloney murine leukemia virus (M-MLV)reverse transcriptase $\mathrm{RNase} \mathrm{H}^{-}$recombinant were obtained from Promega (Madison, WI). Vinblastine was stored as a $4 \mathrm{~mm}$ stock in $100 \%$ methanol, and cytochalasin $\mathrm{E}$ was stored as a $4 \mathrm{mg} / \mathrm{ml}$ stock in $100 \%$ dimethylsulfoxide, both at $-20^{\circ} \mathrm{C}$.

\section{Cell culture}

Sympathetic chain ganglia were dissected out of 9-11 d chicken embryos and grown either as whole ganglia or dissocialed neurons in C-medium (Leibowitz L-15 medium supplemented with $10 \%$ fetal bovine serum, 0.6 mM glucose, $2 \mathrm{mM}$ L-glutamine, $100 \mathrm{U} / \mathrm{ml}$ penicillin, $100 \mu \mathrm{g} / \mathrm{ml}$ streptomycin, $50 \mathrm{ng} / \mathrm{ml} 2.5 \mathrm{~S}$ mouse nerve growth factor and $0.5 \%$ methylcellulose) as described previously (Hollenbeck, 1993). For immunofluorescence or in situ hybridization experiments, neurons were grown at low density in 12-well plates on $15 \mathrm{~mm}$ glass round coverslips coated with 1 $\mathrm{mg} / \mathrm{ml}$ poly-L-lysine overnight at $4^{\circ} \mathrm{C}$ followed by $0.1 \mu \mathrm{g} / \mathrm{ml}$ laminin treatment for $1 \mathrm{hr}$ at $25^{\circ} \mathrm{C}$. For axon isolation, whole ganglia were plated onto poly-L-lysine-coated plastic dishes and grown in C-medium for $4-7 \mathrm{~d}$ at $37^{\circ} \mathrm{C}$.

\section{Drug treatments}

To obtain neurites lacking one cytoskeletal element, dissociated neurons from three sympathetic chains were plated on coverslips in a 12-well plate and incubated at $37^{\circ} \mathrm{C}$ for $30 \mathrm{~min}$ before adding any drug. To obtain axons lacking MTs, medium containing $100 \mathrm{nM}$ vinblastine was then added and cells were grown for $18 \mathrm{hr}$ before fixation (Lamoureux et al., 1990). To obtain axons lacking MFs, medium containing $20 \mathrm{ng} / \mathrm{ml}$ cytochalasin $\mathrm{E}$ was added at $30 \mathrm{~min}$ and cells were grown for $3 \mathrm{~d}$ before fixation (Marsh and Letourneau, 1984). To depolymerize MTs of neurons in established cultures, dissociated sympathetic neurons were plated on coverslips in a 12 -well plate, grown for $18 \mathrm{hr}$ at $37^{\circ} \mathrm{C}$, and treated with $1 \mu \mathrm{M}$ vinblastine for $1 \mathrm{hr}$ before fixation (Morris and IIollenbeck, 1995). To disrupt MFs of neurons in established cultures, dissociated neurons were plated and grown the same way, but were treated with $20 \mathrm{ng} / \mathrm{ml}$ cytochalasin E for $1 \mathrm{hr}$ before fixation (Morris and Hollenbeck, 1995).

\section{Probe preparation}

Synthetic oligo(dT) (32 nucleotides) and oligo(dA) (32 nucleotides) were $3^{\prime}$ end-labeled with digoxigenin-11dUTP using terminal transferase $[0.2$ $\mu \mathrm{M}$ oligonucleotide, $60 \mu \mathrm{M}$ digoxigenin dUTP, $200 \mathrm{~mm}$ potassium cacodylate, $25 \mathrm{~mm}$ Tris- $\mathrm{HCl}$, pH 6.6, $0.25 \mathrm{mg} / \mathrm{ml} \mathrm{BSA,} 2.5 \mathrm{mM} \mathrm{CoCl}_{2}, 0.1 \mathrm{~mm}$ dithiothreitol (DTT), and $1500 \mathrm{U} / \mathrm{ml}$ terminal transferase] at $37^{\circ} \mathrm{C}$ for 1 hr. Probes were then ethanol-precipitated, resuspended in $50 \mu$ lof diethyl pyrocarbonate (DEPC)-treated $\mathrm{H}_{2} \mathrm{O}$ and purified on a $\mathrm{G} 50$ Sephadex column. The incorporation of digoxigenin-11dUTP was quantified by blotting the probes onto nitrocellulose and by detection with an antidigoxigenin-alkaline phosphatase conjugate.

\section{Fixation, immunofluorescence, and in situ hybridization}

For immunofluorescence experiments, cells were washed in warm HBSS, fixed for $15 \mathrm{~min}$ in the same solution containing $2 \%$ formaldehyde, $0.1 \%$ glutaraldehyde, $2 \mathrm{~mm}$ EGTA, $0.12 \mathrm{~m}$ sucrose, and $0.5 \%$ Triton X-100, transferred for $10 \mathrm{~min}$ to the same fixation solution without detergent, then washed in a large volume of PBS, blocked for $15 \mathrm{~min}$ in $3 \%$ BSA in PBS, and processed for immunostaining. To visualize tubulin, cells were incubated for $45 \mathrm{~min}$ at $37^{\circ} \mathrm{C}$ with $\mathrm{YL} 1$ rat monoclonal anti-tubulin in PBS containing $1 \%$ BSA and $0.05 \%$ Triton X-100, washed thoroughly in the same buffer, incubated for $30 \mathrm{~min}$ at $37^{\circ} \mathrm{C}$ with fluorescein isothiocyanate (FITC)-conjugated rabbit anti-rat IgG diluted in the same buffer. To visualize neurofilaments, incubation with a rabbit antiserum against the chick $70 \mathrm{~K}$ neurofilament subunit (Fekete and Brockes, 1987) was followed by incubation with FITC-conjugated goat anti-rabbit IgG. To visualize F-actin, $5 \mu \mathrm{g} / \mathrm{ml}$ rhodamine-phalloidin was added simultaneously with secondary antibodies for double-labeling experiments. Coverslips were washed and mounted as described previously (Hollenbeck and Bray, 1987).

The procedure used for in situ hybridization was derived from the protocol of Bassell et al. (1994). Cells were fixed with 4\% p-formaldehyde in PBS containing $4 \%$ sucrose and $5 \mathrm{~mm} \mathrm{MgCl}_{2}$. Fixed cells were kept in PBS containing $5 \mathrm{~mm} \mathrm{MgCl}_{2}\left(\mathrm{PBS} / \mathrm{MgCl}_{2}\right.$ ) overnight at $4^{\circ} \mathrm{C}$, then washed in PBS $/ \mathrm{MgCl}_{2}$ and permeabilized in $0.3 \%$ Triton X-100 in PBS/ $\mathrm{MgCl}_{2}$ for $5 \mathrm{~min}$ at $25^{\circ} \mathrm{C}$. Coverslips were then successively incubated in $1 \times \mathrm{SSC} / 10$ $\mathrm{mm}$ sodium phosphate, $\mathrm{pH} 7.0,2 \times \mathrm{SSC} / 10 \mathrm{~mm}$ sodium phosphate, $\mathrm{pH}$ 7.0 , for $5 \mathrm{~min}$ at $25^{\circ} \mathrm{C}$ and, finally, in $15 \%$ formamide/2× SSC/10 mM sodium phosphate, $\mathrm{pH} 7.0$, for $10 \mathrm{~min}$ at $37^{\circ} \mathrm{C}$. Five microliters of probe (20 ng) were dried down with Escherichia coli tRNA $(20 \mu \mathrm{g})$ and resuspended in $15 \mu \mathrm{l}$ of $30 \%$ formamide $/ 20 \mathrm{~mm}$ sodium phosphate, $\mathrm{pH} 7.0$. Probes were mixed with $15 \mu \mathrm{l}$ of hybridization buffer ( $4 \times$ SSC, $0.4 \%$ BSA, $20 \mathrm{~mm}$ vanadyl adenosine complex, $10 \mathrm{~mm}$ EDTA, $20 \mathrm{~mm}$ sodium phosphate, and $20 \%$ dextran sulfate, $\mathrm{pH} 7.0$ ). Coverslips were placed cell side down on Parafilm containing $30 \mu l$ of probe mixture and hybridized overnight at $37^{\circ} \mathrm{C}$. After hybridization, coverslips were successively washed at $37^{\circ} \mathrm{C}$ for $20 \mathrm{~min}$ in $15 \%$ formamide $2 \times \mathrm{SSC} / 10 \mathrm{~mm}$ sodium phuspliate, then for 10 min in $15 \%$ formamide $/ 1 \times \mathrm{SSC} / 10 \mathrm{~mm}$ sodium phosphate, followed by three $10 \mathrm{~min}$ washes in $1 \times \mathrm{SSC} / 10 \mathrm{~mm}$ sodium phosphate at $25^{\circ} \mathrm{C}$. Cells were then equilibrated in maleate buffer $(100$ mM sodium maleate, $\mathrm{pH} 7.0$, and $150 \mathrm{mM} \mathrm{NaCl}$ ) and incubated for $15 \mathrm{~min}$ at $25^{\circ} \mathrm{C}$ in maleate buffer with $3 \%$ blocking reagent. Probes were detected using HRP-conjugated sheep anti-digoxigenin and Cy3-conjugated rabbit anti-HRP. Antibody incubations were for $45 \mathrm{~min}$ at $37^{\circ} \mathrm{C}$ in $1 \%$ blocking reagent, $0.1 \%$ Triton $\mathrm{X}-100$ followed by several washes in $\mathrm{PBS} / \mathrm{MgCl}_{2}$. Cy3 was visualized with a Nikon microscope using a rhodamine filter set and a $63 \times$ plan-Neofluar objective and photographed with Kodak TMAX 400 film. As controls for the specificity of in situ hybridization, 
digoxigenin labeled oligo(d $\Lambda)$ probes were hybridized in parallel to digoxigenin-labeled oligo(dT) probes in all experiments. For RNase treatment, fixed and permeabilized cells were incubated with a mixture of RNases (RNase A, $0.2 \mathrm{mg} / \mathrm{ml}$; RNase T1, $0.2 \mathrm{mlg} / \mathrm{mll}$; RNase T2, 100 $\mathrm{U} / \mathrm{ml}$ ) for $30 \mathrm{~min}$ at $37^{\circ} \mathrm{C}$ before hybridization.

\section{Isolation of pure axons}

After $4-7 \mathrm{~d}$ in culture, whole explanted ganglia developed a radial halo of axons long enough to be mechanically isolated from the somatic mass by microdissection as described by Peng et al. (1986). After several gentle washes with warm HBSS, axons of selected halos were cut out, detached from the dish by gentle pipeting with HBSS, and immediately put into Eppendorf tubes containing ice-cold HBSS. Their corresponding somatic mass was also recovered and placed into a separate tube. To prevent any contamination from the cell bodies, axons of each halo were cut at a distance from the somatic mass. The proliferation of fibroblasts was avoided almost completely by treatment of the dish with $1 \mathrm{mg} / \mathrm{ml}$ polyL-lysine. The residual fibroblasts remained attached to the dish when halos of axons were removed from the dish by gentle pipeting.

\section{$R N A$ extraction}

Twenty to fifty axonal halos were required to detect specific, ethidium bromide-stained bands on a polyacrylamide gel after the extraction of total axonal RNA and 30 cycles of amplification by RT-PCR. Total RNAs from axons and the somatic mass were prepared based on the rapid one-step procedure of Chomczynski and Sacchi (1987). Axonal halos and somatic masses were pelleted in separate tubes for $5 \mathrm{~min}$ at $500 \times g$, washed in ice-cold PBS, resuspended in $200 \mu \mathrm{l}$ of denaturing solution ( $4 \mathrm{M}$ guanidium thiocyanate, $42 \mathrm{~mm}$ sodium citrate, $0.83 \% \mathrm{~N}$-lauryl sarcosine, and $0.2 \mathrm{~mm}$ 2-mercaptoethanol), and transferred to DEPCtreated Eppendorf tubes, in which the material was lysed on ice by pipeting. The first extraction of the total RNA was performed by adding $20 \mu \mathrm{l}$ of $2 \mathrm{M}$ sodium acetate, $\mathrm{pH} 4.0$, and $200 \mu \mathrm{l}$ of phenol/chloroform/ isoamyl alcohol $(25: 24: 1)$. After $5 \mathrm{~min}$ on ice, the lysate was centrifuged for $20 \mathrm{~min}$ at $10,000 \times \mathrm{g}$ at $4^{\circ} \mathrm{C}$, and RNAs were precipitated from the upper aqueous phase with an equal volume of isopropanol overnight at $-20^{\circ} \mathrm{C}$ using DNase/RNase-free E. coli $5 \mathrm{~S}$ rRNA $(10 \mu \mathrm{g})$ as carrier. An additional purification step for the RNAs was performed by resuspending the pellet in $200 \mu \mathrm{l}$ of denaturing solution. After an isopropanol precipitation at $-20^{\circ} \mathrm{C}$ for $30 \mathrm{~min}$, RNA pellets were washed with ice-cold $75 \%$ ethanol, dried, resuspended in $50 \mu \mathrm{l}$ of DEPC-treated $\mathrm{H}_{2} \mathrm{O}$ and stored at $-20^{\circ} \mathrm{C}$ until use.

\section{RT-PCR amplification}

Reverse transcription. To perform the RT-PCR amplification of axonal and somatic total RNA under conditions and with RNA quantities as similar as possible, a sample of somatic RNA equivalent to that of the somatic mass of 1 ganglion was reverse-transcribed into cDNA in parallel with the RNA from 20-50 axonal halos. RNA pellets were resuspended in $20 \mu \mathrm{l}$ of $\mathrm{RT}$ solution [ $50 \mathrm{~mm}$ Tris-HCl, $\mathrm{pH} 8.3,75 \mathrm{mM} \mathrm{KCl}, 3 \mathrm{~mm}$ $\mathrm{MgCl}_{2}, 10 \mathrm{~mm}$ DTT, $1 \mathrm{~mm}$ of each dNTP, and $2.5 \mu \mathrm{M}$ oligo $\left.\left(\mathrm{dT}_{16}\right)\right]$. This mixture was heated to $80^{\circ} \mathrm{C}$ for $5 \mathrm{~min}$ and slowly cooled to $42^{\circ} \mathrm{C}$ to optimize the primer annealing. Twenty units of RNasin ribonuclease inhibitors and $200 \mathrm{U}$ of M-MLV-reverse transcriptase $\mathrm{RNase}^{-}$recombinant were then added to each tube. The mixture was incubated for 30 $\min$ at $42^{\circ} \mathrm{C}$. The reaction was stopped by inactivation of the enzyme at $95^{\circ} \mathrm{C}$ for $5 \mathrm{~min}$.

$\beta$-actin and $\alpha$-tubulin $c D N A$ PCR coamplification. To avoid an additional ethanol precipitation, axonal and somatic single-strand CDNA were diluted $1: 5$ and 1:100, respectively, in $50 \mathrm{~mm} \mathrm{KCl}, 10 \mathrm{~mm}$ Tris $-\mathrm{HCl}, \mathrm{pH}$ 8.3 , and used as stocks for each reaction of PCR amplification. Secondstrand synthesis and coamplification of $\beta$-actin and $\alpha$-tubulin cDNA by PCR were performed by using, respectively, oligonucleotide primers $\left(5^{\prime}\right.$ primer CBAl: 5'-AIGGATGAIGAIATTGCTCCC-3' corresponding to nucleotides $1-21$ of the $\beta$-actin coding sequence; 3 'primer CBA2: $5^{\prime}$-GGTGACAATACCGTGTTCAAT- $3^{\prime}$ complementary to the $\beta$-actin coding sequence 531-552), and oligonucleotide primers $\left(5^{\prime}\right.$ primer TUB1: 5'-ATCGCCACCATCAAGACCAA-3' corresponding to codon 331-338 of the $\alpha$-tubulin coding sequence; 3'primer TUB2: 5'CAGGTCAAACTTGTGGTCCA-3' complementary to the $\alpha$-tubulin coding sequence 390-396), defined from the chicken cDNA sequences (Valenzuela et al., 1981; Kost et al., 1983). Each primer (10 pmol total) was ${ }^{32} \mathrm{P} 5$ ' end-labeled in a single tube using the T4 polynucleotide kinase and purified on a G50 Sephadex column. PCR coamplifications were done in a $50 \mu \mathrm{l}$ reaction volume using hot start conditions: a first "lower" mix $(12.5 \mu \mathrm{l})$ containing $0.2 \mathrm{~mm}$ of each dNTP, $2.0 \mathrm{mM} \mathrm{MgCl}_{2}, 0.1 \mathrm{mg} / \mathrm{ml}$ acetylated BSA, and $0.2 \mu \mathrm{M}$ of each unlabeled primer CBA2 and TUB2 was added to each tube, topped with an AmpliWax PCR Gem50 plug, which was melted to form a tight seal by incubating the tubes at $70^{\circ} \mathrm{C}$ for $2 \mathrm{~min}$. An "upper" $\operatorname{mix}(37.5 \mu \mathrm{l})$ containing $50 \mathrm{~mm} \mathrm{KCl}, 10 \mathrm{~mm}$ Tris- $\mathrm{HCl}$, $\mathrm{pH} 8.3,0.2 \mu \mathrm{M}$ of each unlabeled primer CBAl and TUBI, $1.25 \mathrm{U}$ AmpliTaq DNA polymerase, $5 \mu$ lof the stock single strand cDNA sample and $1 \mu \mathrm{l}(150,000 \mathrm{cpm} / \mu \mathrm{l})$ corresponding to $1: 50$ of the ${ }^{32} \mathrm{P}$-labeled primer mix, was added on the top of the solid AmpliWax and covered with $25 \mu \mathrm{l}$ of mineral oil. Tubes were placed in a TwinBlocks DNA thermal cycler (Ericomp, San Diego, CA) and reactions started with one-step denaturation at $95^{\circ} \mathrm{C}$ for $2 \mathrm{~min}$, followed by 32 cycles of amplification $(30 \mathrm{sec}$ at $95^{\circ} \mathrm{C}, 30 \mathrm{sec}$ at $55^{\circ} \mathrm{C}, 1 \mathrm{~min}$ at $72^{\circ} \mathrm{C}$ ) and one final extension for $5 \mathrm{~min}$ at $72^{\circ} \mathrm{C}$. Five microliter aliquots were taken every 2 cycles from each reaction mixture after $20-32$ cycles and loaded on a $5 \%$ polyacrylamide/ $7 \mathrm{M}$ urea gel that was dried by vacuum suction and exposed to Kodak XAR-OMAT film at $-80^{\circ} \mathrm{C}$ for $5 \mathrm{~d}$, or analyzed by PhosphorImaging (Molecular Dynamics, Sunnyvale, CA).

\section{RESULTS}

\section{Polyadenylated mRNA distribution in cultured sympathetic neurons}

We tested for the presence of poly $\left(\mathrm{A}^{+}\right)$mRNA in growing sympathetic axons using fluorescence in situ hybridization with digoxygenin-labeled oligo(dT) probes, followed by primary and secondary antibodies. The high sensitivity and resolution of the technique were mainly attributable to the use of secondary antibodies conjugated to the highly fluorescent dye Cy3. Under our culture conditions, sympathetic neurons elaborate axonal processes (Baas and Ahmad, 1992, 1993) extending well over $200 \mu \mathrm{m}$ in length by $24 \mathrm{hr}$, and sometimes branching. When these cells were subjected to in situ hybridization with labeled oligo(dT) probes, the strongest signal was in the soma, but it was also detected along the axons of most neurons in a bright, punctate pattern suggesting a clustering of mRN $\Lambda$ s (Fig. 1A,B). The hybridization signal was always more intense in the proximal part of the axon; however, brightly labeled clusters of mRNA were clearly detected in the distal regions, particularly at axonal branch points, varicosities, and at some growth cones (Figs. $1 A, B, 3$ ). This signal was abolished by treatment of the cultures with RNases before incubation with oligo(dT) probes (Fig. $1 C, D$ ) and was absent from cultures incubated with labeled oligo(dA) probes (Fig. $1 E, F$ ). Thus, the oligo(dT) hybridization signal is specific and reports the location of poly $\left(\mathrm{A}^{+}\right)$mRNA, although it is possible that other RNAs with unusually long A-rich regions may also contribute to the signal. Moreover, the mRNA clusters were clearly detected in most axonal branches but absent from others (Figs. 1B, 3B), providing additional evidence that the hybridization is highly specific.

We then analyzed the distribution of poly $\left(\mathrm{A}^{+}\right)$mRNA within the axon in neurons fixed at specific stages of development and found that it varied with the extent of axonal outgrowth (Fig. 2). Axons of neurons cultured for only $2 \mathrm{hr}$ were $\sim 50 \mu \mathrm{m}$ long, unbranched, and possessed elaborate growth cones in which the poly $\left(\mathrm{A}^{+}\right)$mRNA signal was routinely concentrated (Fig. $2 A, B$ ). The signal intensity within these short axons was not significantly greater than that obtained in the proximal portion of longer axons. As neurons were cultured for $8 \mathrm{hr}$ and axons extended farther, poly $\left(\mathrm{A}^{+}\right)$mRNA became distributed in a punctate pattern along the axon shaft, and although it persisted in many growth cones, became less intense there (Fig. $2 C, D$ ). After $>8 \mathrm{hr}$ of growth, axons of most neurons started to form collateral branches and, although poly $\left(\mathrm{A}^{+}\right)$mRNA in these neurons remained distributed in a punctate pattern along the axon, the signal 

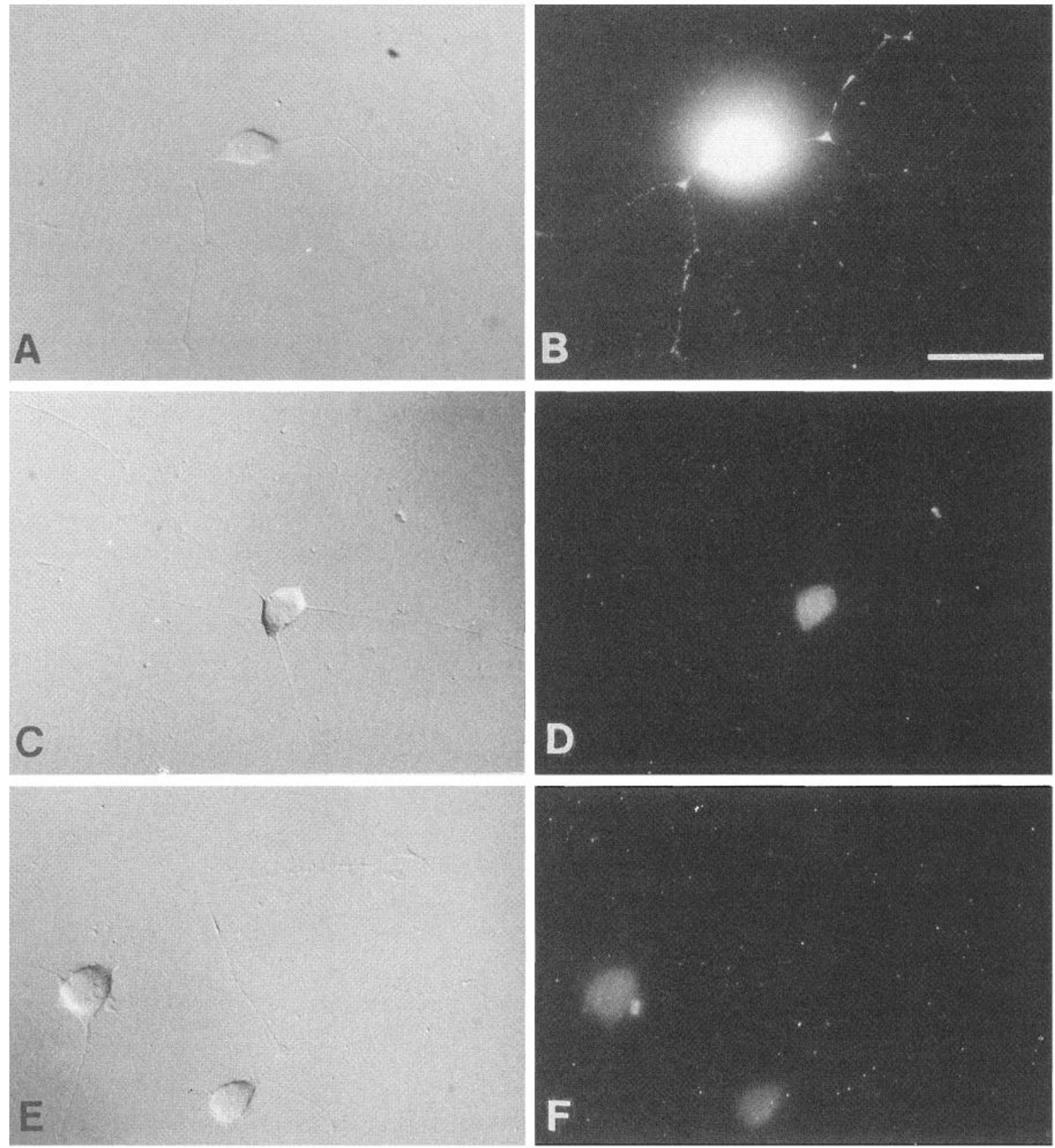

Figure 1. In situ hybridization of sympathetic neurons with fluorescently labeled oligo(dT) probes and corresponding controls. A differential interference contrast (DIC) image $(A, C, E)$ and fluorescence image $(B, D, F)$ are shown for each field. Comparison of the DIC image in $A$ with the corresponding fluorescent in situ image in $B$ revealed bright staining in the soma, as well as staining in the axonal growth cones, branch points, and along the axonal shafts in a punctate pattern. Cultures treated with RNase before in situ hybridization $(C, D)$ showed a gross reduction in somatic staining and no axonal staining. Cultures probed with identically labeled oligo $(\mathrm{dA})(E, F)$ showed no staining above background. Scale bar, $20 \mu \mathrm{m}$.

became particularly concentrated at axonal branch points and was sparser elsewhere (Fig. 2E,F). After $>1 \mathrm{~d}$ in culture, neurons generated very long axons in which the total signal in the distal regions appeared to decrease, but axonal branch points and varicosities remained brightly labeled and were the principal sites of poly $\left(\mathrm{A}^{+}\right)$mRNA localization (Fig. 3). The range of patterns of hybridization observed in longer neurons is reflected in the two examples shown in Figure 3, which illustrate both punctate staining along the axon shaft (Fig. $3 B$ ) and concentrated staining at branch points and varicosities (Fig. $3 D$ ). It should be noted that much longer axons, which could not be shown over their entire length, had similar patterns of staining, such that the poly $\left(\mathrm{A}^{+}\right)$ mRNA was detected at distances considerably greater than 300 $\mu \mathrm{m}$ from the soma.

It was notable that poly $\left(\mathrm{A}^{+}\right)$mRNA was not found to be distributed equivalently in the different collateral branches of the same axons: signal was clearly detected in some axonal branches (e.g., Fig. $3 B$, main shaft), whereas in others, little if any hybridization was observed [Fig. 3, $B$ (small branches) and $D$ (upper right branches)]. Moreover, in long axons, the intensity of staining in the growth cones was lower in axons with larger numbers of branches (not shown). 

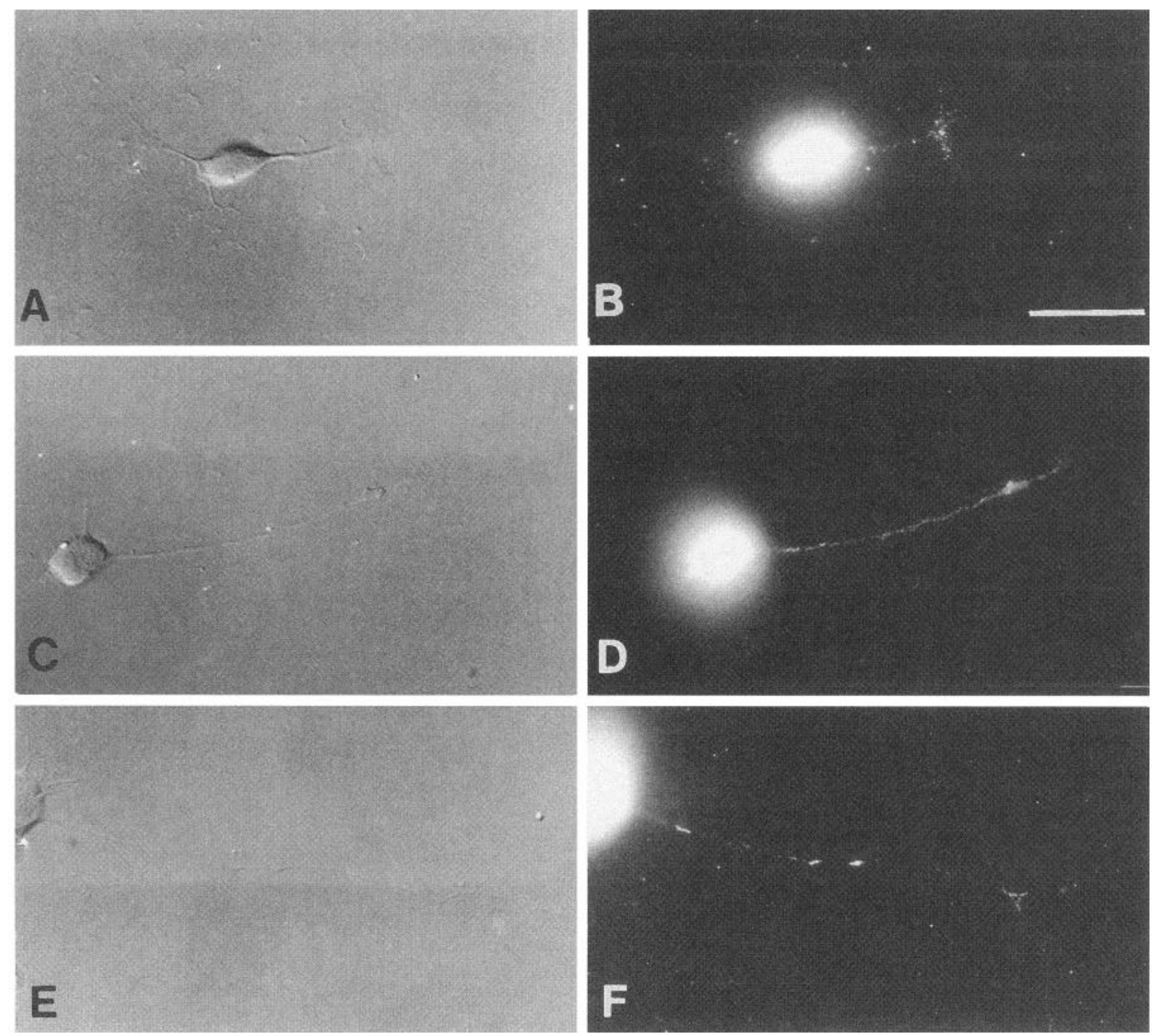

Figure 2. Distribution of poly $\left(\mathrm{A}^{+}\right)$mRNA at different stages in axonal outgrowth. After $2 \mathrm{hr}$ in culture $(A, B)$ fluorescent in situ hybridization showed that the growth cone and axon shaft contained mRNA. By $8 \mathrm{hr}(C, D)$, the signal was distributed along the growing axon shaft and was less prominent in the growth cone. After $>16 \mathrm{hr}$ of growth $(E, F)$, axons showed the signal distributed in a punctate fashion along their shafts and concentrated at branch points. Scale bar, $20 \mu \mathrm{m}$.

\section{$\beta$-actin mRNA, but not $\alpha$-tubulin mRNA, is detected in axons by RT-PCR amplification}

We chose $\beta$-actin mRNA as a candidate for axonal localization because it is found to be selectively located at the leading edge of motile non-neuronal cells, where its translation presumably supports the prolific actin polymerization characteristic of this region (Lawrence and Singer, 1986; Taneja and Singer, 1990; Hill and Gunning, 1993). The axonal growth cone has very similar structural and motile properties to the leading edge of other polarized cells (Bray and Hollenbeck, 1987; Heidemann and Buxbaum, 1991), including a dense network of locally polymerized actin (Sobue, 1993). In addition, because the extreme length of the axon places the growth cone at a considerable distance from the synthetic capacity of the neuronal soma, we reasoned that $\beta$-actin mRNA could be an important mRNA species within the axon. To obtain adequate sensitivity to detect an individual axonal RNA species, we used RT-PCR amplification of total axonal RNA. Using RNA isolated from either axons or cell bodies of sympathetic neurons as described in Materials and Methods (Fig. 4), we amplified the $\beta$-actin mRNA by RT-PCR using $\beta$-actin-specific primers. After 30 cycles of amplification, PCR products of the expected size (231 nucleotides) were detected by ethidium bromide staining of polyacrylamide gels (not shown). Then, to determine whether the axonal mRNA pool differed significantly from the somatic pool, as well as to assess the possibility of minor contamination from cell bodies in the axonal RNA preparation, we coamplified $\beta$-actin mRNA and $\alpha$-tubulin mRNA from both the axonal and somatic RNA extracts. Tubulin was chosen because its mRNA has been reported to be exclusively located in the soma of sympathetic developing neurons (Bruckenstein et al., 1990 ) and because $\beta$-actin and $\alpha$-tubulin are both major structural proteins of the neuron.

For the $\beta$-actin/ $\alpha$-tubulin cDNA coamplification to report accurately the ratio of the respective mRNAs in the original compartments, (1) a set of $\alpha$-tubulin-specific primers was chosen that would generate PCR fragments of similar size to those obtained with the $\beta$-actin primers, because the rate of amplification is directly related to the size of the DNA to be amplified; (2) experimental conditions were established under which $\beta$-actin and $\alpha$-tubulin cDNAs were the only fragments amplified without significantly affecting their respective amplification rates; (3) a number of PCR cycles was chosen that was low enough to provide 

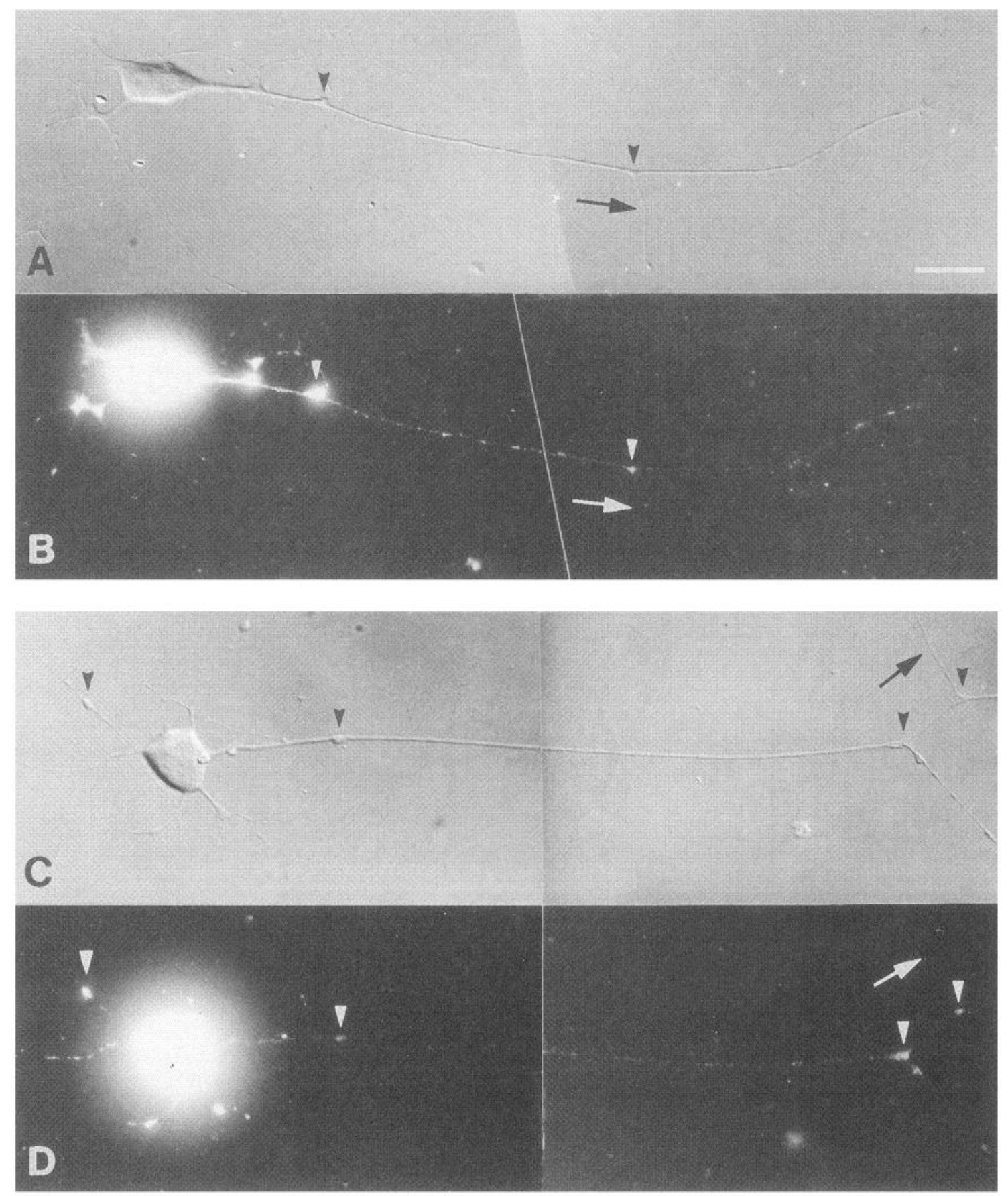

Figure 3. Changing distribution of mRNA in very long axons. Paired DIC $(A, C)$ and fluorescent in situ images $(B, D)$ of axons after $>1 \mathrm{~d}$ of outgrowth showed that the punctate mRNA signal distributed along the axon shafts was decreased in quantity compared with earlier stages but still present $(B, D)$, whereas axonal branch points and varicosities were brightly labeled (arrowheads). In addition, most branches contained mRNA label, whereas a fraction lacked label entirely (arrows). Scale bar, $20 \mu \mathrm{m}$.

optimal amplification for both primers, but high enough to detect the $\beta$-actin PCR products in the axonal compartment. To amplify under conditions as similar as possible from the axonal and somatic compartments, we adjusted the starting quantities of the axonal and somatic mRNA in the RT procedure, and of the resulting single-stranded cDNAs in the PCR procedure, to use comparable starting quantities of material at both steps (see Materials and Methods). ${ }^{32} \mathrm{P}$-labeled $\beta$-actin and $\alpha$-tubulin primers were added to the PCR reaction mixture to detect $\beta$-actin PCR products after as few as 20 cycles of amplification of the axonal compartment cDNA. Aliquots of the PCR reaction mixture taken at $22,24,26,28$, and 30 cycles of the amplification were directly loaded on a $5 \%$ polyacrylamide/urea denaturing gel, and the separated PCR labeled products were analyzed using PhosphorImaging. As shown in Figure $4 C$, whereas $\beta$-actin PCR products were found in similar amounts in both the axonal and somatic compartments, $\alpha$-tubulin PCR products were detected only in the somatic compartment even after 30 cycles of amplification. Over the range of cycles examined, the rates of $\beta$-actin amplification were virtually identical for the axonal and somatic material. Al- 

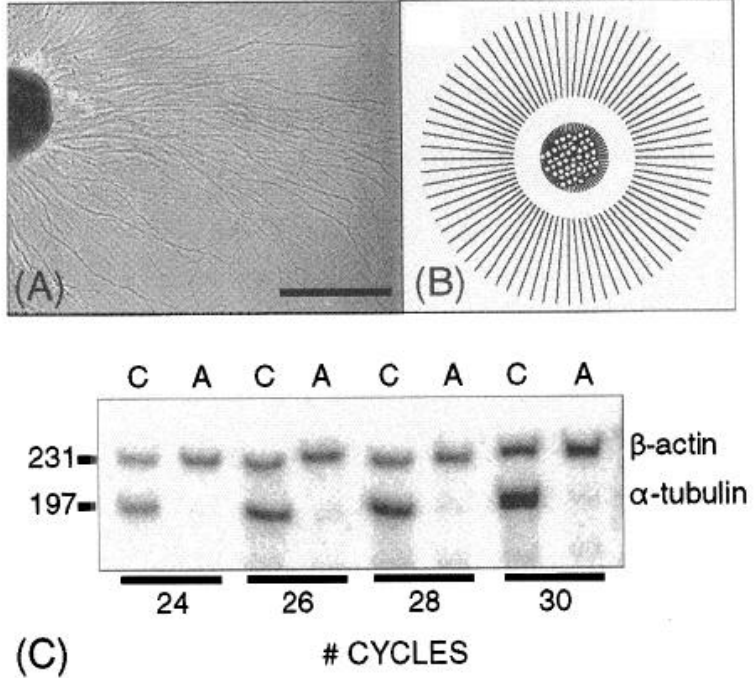

Figure 4. Analysis of $\beta$-actin and $\alpha$-tubulin in somatic versus axonal mRNA populations. $A$, Phase-contrast micrograph of a portion of the axonal halo emanating from one cell body mass (left). Scale bar, $500 \mu \mathrm{m}$. $B$, Schematic diagram of the physical separation of extended axonal halos (periphery) from their corresponding cell bodies (center) to obtain material for the extraction of somatic versus axonal RNA. $C$, PhosphorImager analysis of the coamplification of the $\beta$-actin and $\alpha$-tubulin fragments from cell body ( $C$ lanes) and axonal ( $A$ lanes) cDNA samples. After the number of cycles shown at the bottom, $5 \mu \mathrm{l}$ aliquots of the PCR products were withdrawn from each sample, separated on polyacrylamide/urea gels, and visualized. Both the $\beta$-actin fragment (231 nucleotides) and the $\alpha$-tubulin fragment (197 nucleotides) were amplified from the cell body sample, with no significant change in their ratio throughout this range of amplification, whereas the $\beta$-actin PCR fragment alone was amplified from the axonal sample with no evidence of the $\alpha$-tubulin fragment even after 30 cycles of amplification.

though the rate of the amplification was linear for both sets of primers in the range of $24-30$ cycles, the $\beta$-actin: $\alpha$-tubulin ratio in the somatic preparations remained nearly unchanged throughout the procedure, and the small difference in the rate of amplification actually favored $\alpha$-tubulin. Thus, the fact that $\alpha$-tubulin mRNA was not detected in the axonal compartment leads us to conclude that mRNA encoding $\beta$-actin, but not $\alpha$-tubulin, is one of the poly $\left(\mathrm{A}^{+}\right)$mRNAs detected in axons of peripheral neurons and is not a somatic contaminant. These results indicate that $\alpha$-tubulin mRNA, although prominently expressed in the soma, is not represented in the axonal mRNA population, and that $\beta$-actin mRNA is a bona fide resident of the axonal compartment. Thus, the two compartments differ in their mRNA complement of two major structural proteins of the cell, and the absence of $\alpha$-tubulin products apparently constitutes, in this system, an appropriate control for somatic contamination of axonal preparations.

\section{Poly $\left(\mathrm{A}^{+}\right)$mRNA distribution in neurons grown lacking MTs or MFs}

The previous result indicated the presence of one major neuronal mRNA species in the axon and the exclusion of another, suggesting that axonal mRNAs constitute a subpopulation of the total mRNA expressed in these neurons in culture, and that their presence within the axon must be the result of an active and selective transport. Because recent studies in neurons and nonneuronal cells have implicated MTs, MFs, and intermediate filaments in the translocation and anchoring of mRNAs (Yisraeli et al., 1990; Sundell and Singer, 1991; Ainger et al., 1993; Bassell et al., 1994; Ferrandon et al., 1994; Litman et al., 1994; Pokrywka and Stephenson, 1995), we selectively disrupted elements of the cytoskeleton in cultured neurons by the use of specific drugs and examined the effects on the distribution of poly $\left(\mathrm{A}^{+}\right)$mRNA.

First, we grew sympathetic neurons in the continuous presence of vinblastine, to prevent MT formation, or cytochalasin, to prevent formation of a coherent MF network, and fixed cultures in parallel for immunofluorescence and in situ hybridization with oligo(dT) probes. In the presence of low concentrations of vinblastine in the culture medium, previous studies have already demonstrated the ability of neurons to extend axonal processes lacking MTs, with a decreased axonal caliber, but a normal density of the other cytoskeletal elements (Lamoureux et al., 1990; Morris and Hollenbeck, 1995). The double staining of vinblastine-treated cells with rhodamine-phalloidin and anti-tubulin confirmed that neurons in these conditions were slowly able to extend straight axon-like processes over $100 \mu \mathrm{m}$ in length (Fig. 5), containing robust MFs but lacking MTs. The poly $\left(\mathrm{A}^{+}\right)$mRNA distribution in these cells was found to be exclusively restricted to the soma (Fig. $5 D$ ), suggesting that MTs are involved in the positioning of mRNA in the neurite. This result also indicates that the presence of poly $\left(\mathrm{A}^{+}\right)$mRNA in short axons of control cells (Fig. $2 A, B$ ) is unlikely to be attributable to simple diffusion and is likely to rely on active transport, probably involving MTs. Moreover, the mRNA signal in the soma was significantly reduced in intensity compared with controls, suggesting that at least a fraction of poly $\left(\mathrm{A}^{+}\right)$mRNA in the soma may also interact with the MT network. Neurons grown in the continuous presence of low concentrations of cytochalasin $\mathrm{E}$ also extend neurites, but with a characteristic curly morphology (Fig. $5 E$ ), and requiring $3 \mathrm{~d}$ to achieve the lengths seen in the previous experiment (Marsh and Letourneau, 1984; Morris and Hollenbeck, 1995). Immunofluorescence and rhodamine-phalloidin staining confirmed that these neurites contained normal MT densities but lacked coherent MF arrays (Fig. $5 E, F)$. Poly $\left(\mathrm{A}^{+}\right)$mRNA in cytochalasin-treated neurons was detected all along the processes (Fig. $5 H$ ), in a pattern very similar to that seen in control neurons with axons of similar length (Fig. 2C,D). This result indicates that MF integrity is not necessary for the access and/or transport of mRNA into the neurite.

\section{Effects on the poly $\left(\mathrm{A}^{+}\right)$mRNA distribution of cytoskeletal disruption in established neuronal cultures}

The previous data raised the question of whether the MTs or MFs are also necessary to maintain the axonal localization of mRNA in neurons with established axons. To address this, neurons were grown for $24 \mathrm{hr}$ and then treated with $1 \mu \mathrm{M}$ vinblastine or $20 \mu \mathrm{g} / \mathrm{ml}$ cytochalasin $\mathrm{E}$ for $1 \mathrm{hr}$ before the fixation. Vinblastine treatment eliminated virtually all MTs from the axon (Fig. 6A) (Morris and Hollenbeck, 1995), without affecting the densities of MFs (Fig. $6 B$ ) or of neurofilaments (Morris and Hollenbeck, 1995). This treatment abolished detectable poly $\left(\mathrm{A}^{+}\right)$mRNA from the axon, and hybridization was restricted to the soma of all neurons (Fig. $6 C, D)$. Conversely, cytochalasin treatment, which disrupted MFs almost to the point of elimination from the axon while leaving a robust MT array in place (Fig. 6E,F) (Morris and Hollenbeck, 1995), had no apparent effect on the axonal mRNA distribution as compared with control axons of similar length (Figs. $6 G, H, 2$ ). These observations implicate the MTs, but not the MFs, in the maintenance of the axonal localization of mRNA. 

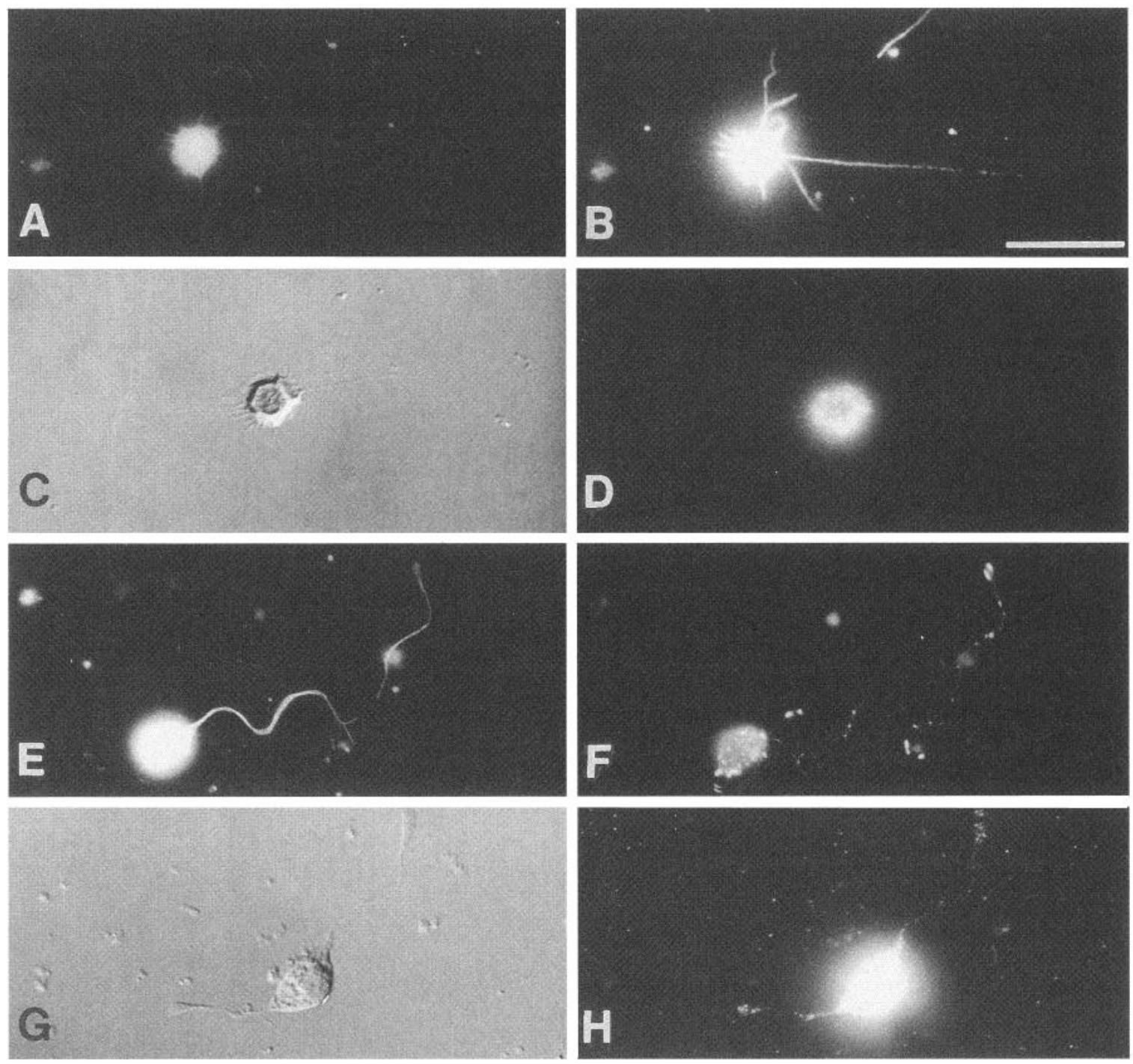

Figure 5. MTs are involved in the positioning of poly $\left(\mathrm{A}^{+}\right)$mRNAs in axons. Sympathetic neurons were grown in the presence of either vinblastine $(A-D)$ or cytochalasin $\mathrm{E}(E-H)$, to generate neurites lacking either MTs or F-actin, respectively. Double-staining of $\alpha$-tubulin $(A, E)$ and $\mathrm{F}$-actin $(B, F)$ shows the selective inhibition of cytoskeletal development in neurons grown continuously for $18 \mathrm{hr}$ in vinblastine $(A, B)$ or for $3 \mathrm{~d}$ in cytochalasin $(E, F)$. In situ hybridization, shown as DIC/fluorescence pairs, illustrates that mRNA is absent from MT-deficient processes $(C, D)$, whereas the mRNA distribution in processes of similar length that contain MTs but have grossly disrupted F-actin $(G, H)$ is indistinguishable from control cells (compare Figs. 1, 2). Scale bars, $20 \mu \mathrm{m}$.

\section{DISCUSSION}

Our purpose in this study was to test directly for the presence of specific axonal mRNAs in growing axons of vertebrate neurons and to gain an initial insight into the mechanisms of their transport. Using fluorescence in situ hybridization and RT-PCR amplification, we have provided direct evidence that axons of chick sympathetic neurons do contain a selective and presumably heterogenous population of poly $\left(\mathrm{A}^{+}\right)$mRNAs, including mRNA encoding $\beta$-actin but not $\alpha$-tubulin. Our results also indicate that the distribution of axonal mRNAs changes during axonal outgrowth and that the transport and/or localization of mRNAs in these axons occurs via an active MT-dependent process.

\section{Presence and distribution of poly $\left(\mathrm{A}^{+}\right) \mathrm{mRNA}$ in axons of sympathetic neurons}

Using oligo(dT) probes and appropriate controls, we observed a significant and specific hybridization signal within axons at all stages of outgrowth, clearly establishing the presence of poly $\left(\mathrm{A}^{+}\right)$ mRNAs in axons of sympathetic neurons. Moreover, because the axonal localization of these mRNAs is dependent on the integrity of MTs (discussed further below), these data suggest that axonal mRNAs are actively transported and anchored to specific binding sites along the axon. Few studies report the subcellular localization of RNA molecules within the axonal domain, and these studies concern the localization of neuropeptide mRNAs by in situ hybridization at the ultrastructural level (for review, see Van Minnen, 1994b). Our results, obtained using light microscope in situ hybridization, not only demonstrate the presence of mRNAs in axons but also show how and where they are localized along the axon shaft during outgrowth. The punctate, granular pattern of mRNA that we observed was similar to that reported in other cases of localized mRNAs (Ainger et al., 1993; Bassell et al., 1994; Ferrandon et al., 1994; Forristall et al., 1995), suggesting that this 

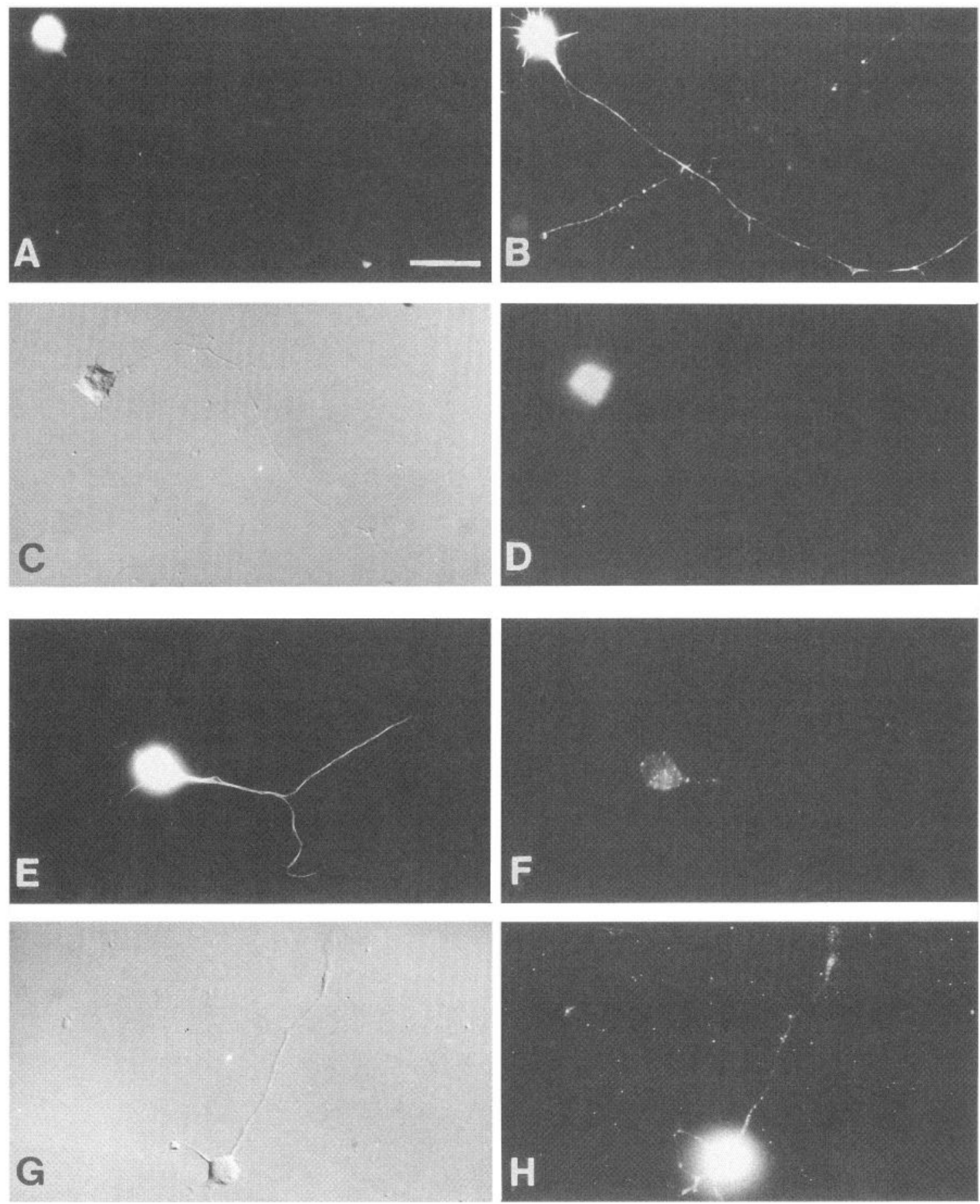

Figure 6. MT integrity is necessary to maintain poly $\left(\mathrm{A}^{+}\right)$mRNA in axons. Established cultures of sympathetic neurons were treated for 1 hr with either vinblastine $(A-D)$ or cytochalasin $\mathrm{E}(E-H)$ to selectively disrupt the MTs or F-actin, respectively. Double-staining of $\alpha$-tubulin $(A, E)$ and F-actin $(B, F)$ shows the selective perturbation of the axonal cytoskeleton. In situ hybridization, shown as DIC/fluorescence pairs, demonstrates that depolymerization of MTs eliminates the mRNA signal $(C, D)$, whereas disruption of F-actin does not disturb the mRNA distribution $(G, H)$. Scale bars, $20 \mu \mathrm{m}$.

organization may be a common feature of localization by active mRNA transport (for review, see St. Johnston, 1995). Although we observed a decrease of the total hybridization signal along the axon during axonal outgrowth, prominent clusters of mRNA remained detectable in axons after several days of growth, hundreds of micrometers from the soma, and became progressively localized to specific regions-virtually all of the branch points and varicosities. Thus, the axons maintain during outgrowth the capacity both to transport and to specifically localize mRNAs. The absence of signal from some branches of individual axons (Figs. $1 A, 3 D$ ) suggests a functional significance for the mRNA localization at branch points: some form of sorting or selective targeting seems likely to occur at branch points, probably soon after their formation. This would be consistent with recent evidence 
that in hippocampal neurons grown in culture different neurites of the same neuron contain a different populations of mRNA (Miyashiro et al., 1994). The presence of mRNAs at varicosities distributed along the axon shaft may also have a biological significance. These structures correspond to local dilations of the axon where mRNAs could be either trapped temporarily among organelles that aggregate at these sites, or specifically docked and sequestered by localized binding sites; the latter seems more likely in view of the tight association of a majority of cellular mRNA with the cytoskeleton (Hesketh and Pryme, 1991; Pachter, 1992; Suprenant, 1993).

The question arises whether axonal mRNA is a general feature of all neurons or a cytotypic specialization of some, because until recently the prevalent view was that protein synthesis occurred exclusively in the somatodendritic domain and that molecules required for the growth, maintenance, and compartmental specificity of the axon were targeted via undetermined intracellular mechanisms (Black and Smith, 1988; Black and Baas, 1989; Kelly and Grote, 1993) for anterograde axonal transport. The rigor and elegance of the body of work characterizing anterograde transport (for review, see Grafstein and Forman, 1980; Brady, 1991; Cleveland and Hoffman, 1991; Nixon, 1991; Vallee and Bloom, 1991; Hirokawa, 1993) have dominated our thinking about the formation of the axonal compartment, and the sheer volume of this flow would seem to obviate any need for local protein synthesis within axons. However, there is a growing body of evidence that in addition to proteins, mRNAs are transported within the axon in invertebrates and vertebrates (for review, see Van Minnen, 1994b). The evidence from invertebrates includes the detection in the squid giant axon of tRNA, rRNA, and active polysomescontradicting the history of negative evidence for translational machinery in the axon-as well as several mRNAs (Perrone Capano et al., 1987; Rapallino et al., 1988; Crispino et al., 1993b), including those encoding the cytoskeletal proteins $\beta$-actin and $\beta$-tubulin (Kaplan et al., 1992), neurofilament protein (Giuditta et al., 1991), and the motor protein kinesin (Gioio et al., 1994). In addition, axons of molluscan peptidergic neurons were found to contain substantial amounts of neuropeptide-encoding mRNAs at a considerable distance from the soma (Landry et al., 1992; Van Minnen, 1994a), suggesting the existence of a sorting and trans port mechanism for axonal mRNAs in these types of neuroendocrine cells (for review, see Van Minnen, 1994b). Finally, in another mollusk, Heliosoma trivolis, isolated growth cones from cultured neurons have been reported to possess the autonomous capacity for protein synthesis (Davis et al., 1992), providing indirect evidence for axonal transport of mRNAs. These latter axons are very short (only a few cell-body diameters), and one could dispute in cell biological terms whether they constitute a separate compartment from the soma.

In vertebrates, the transport of RNAs to the distal portion of axon has been demonstrated in just two types of neuron. In the magnocellular neurons of the hypothalamic neurosecretory system in the rat, mRNAs encoding neuropeptides have been identified and their axonal transport indirectly demonstrated (Jirikowski et al., 1990; Mohr et al., 1991, 1993; Mohr and Richter, 1992; Trembleau et al., 1994). Transcripts encoding several proteins (Mohr and Richter, 1992; Skutella et al., 1994) have also been found in the axonal domain of these cells, as has the untranslated BC1 RNA (Tiedge et al., 1993). In olfactory sensory neurons, the presence (Rogers et al., 1985; Ehrlich et al., 1990; Ressler et al., 1994; Vassar et al., 1994) and transport (Wensley et al., 1995) in axons of mRNA encoding olfactory marker protein have been reported. Thus, varied evidence for the presence of axonal mRNAs now exists for both invertebrate and vertebrate neurons. However, the existence of axonal mRNA transport and localization as a general mechanism to provide a local supply of specific proteins in the distal axon is still not widely accepted. This may be because the extant evidence comes from large invertebrate axons, neurosecretory vertebrate neurons, and neurons that continuously regenerate. By providing direct evidence that axons of vertebrate peripheral neurons in culture do contain a heterogeneous and selective population of poly $\left(\mathrm{A}^{+}\right)$mRNAs, the present study shows that at least one type of cultured neuron with a more conventional axonal compartment possesses the capacity to select and transport mRNAs to the distal portion of axons.

\section{mRNAs are transported and anchored in axons of sympathetic neurons in culture via an MT-dependent process}

The mechanism commonly invoked to explain mRNA localization is active transport along the cytoskeleton (St. Johnston, 1995) followed by anchorage there (Pachter, 1992). To test whether this was the case for axonal mRNA in sympathetic neurons, we selectively disrupted the cytoskeletal elements by growing neurons in the continuous presence of specific inhibitors. Cultures were grown under conditions in which they extend processes devoid of MTs but possessing robust MFs or, conversely, under those conditions that give rise to processes lacking coherent MF arrays but containing a typical density of MTs (Fig. 5) (Marsh and Letourneau, 1984; Lamoureux et al., 1990; Morris and Hollenbeck, 1995). We found that mRNAs were restricted to the soma in all neurons with axons lacking MTs, whereas in axons that lacked MFs the signal was undiminished compared with control axons of similar length. These data indicate that MTs are involved in the access and transport of mRNAs into the axons, whereas MFs are not, and they also strongly favor active transport of mRNAs into the axon over entry by diffusion. This is consistent with reports from a variety of invertebrate and vertebrate cell types, in which mRNA localization is achieved by MT-dependent transport (Yisraeli et al., 1990; Ainger et al., 1993; Bassell et al., 1994; Ferrandon et al., 1994; Litman et al., 1994; Pokrywka and Stephenson, 1995). The access of mRNA to the axon in the presence, but not the absence, of MTs also argues against hypotheses that invoke the dense MT array of the axon hillock as an exclusion "filter" for mRNAs or mRNP particles (Steward and Banker, 1992). In any case, the entry of large organelles such as mitochondria into and along the axon (Morris and Hollenbeck, 1993) makes it unlikely that the axonal cytoskeleton serves as a physical barrier to active transport.

MT integrity was also necessary to maintain mRNA localization in axons, suggesting anchorage of mRNAs to axonal MTs. In established cultures, selective disruption of MFs had no significant effect on the mRNA localization in axons, whereas MT depolymerization abolished detectable axonal mRNA. The disappearance of signal that had been present throughout the axon within 1 hr of MT disruption seems likely to involve one or both of two phenomena: the displacement from focal anchoring sites may have caused mRNAs to become too diffusely distributed to be detected by our methods, or it may have increased their rate of degradation, perhaps through increased accessibility to RNases as reported by Berleth et al. (1988). This could also explain the significant diminution of signal that we also observed in cell bodies under conditions of MT disruption (Fig. 6D). 
Only a subpopulation of $m R N A$ is transported in axons of sympathetic neurons in culture

In view of our data showing that axons contain actively transported poly $\left(\mathrm{A}^{+}\right)$mRNAs, we examined whether the system of mRNA transport in axons showed some specificity. Among many possible candidates for axonal localization are mRNAs encoding proteins required in the distal axon, such as cytoskeletal proteins, those used mainly there, such as synapsins, or those associated with outgrowth, such as growth-associated protein-43. We chose to coamplify $\beta$-actin and $\alpha$-tubulin mRNAs by RT-PCR to address the question of the selectivity of axonal transport because they are both major neuronal proteins, tubulin mRNA is reported to be restricted to the somatodendritic compartment (Bruckenstein et al., 1990; Kleiman et al., 1990), and $\beta$-actin mRNA is specifically translocated and translated at the leading edge of migrating fibroblasts (Lawrence and Singer, 1986; Taneja and Singer, 1990), a cytoplasmic domain having similar properties to the axonal growth cone (Bray and Hollenbeck, 1987). Using carefully chosen and controlled amplification conditions, we found that mRNA encoding $\beta$-actin was present in axons of peripheral neurons, whereas $\alpha$-tubulin mRNA was restricted to the somatic compartment. These results show that the mRNA populations in the axonal and somatic compartments are qualitatively different: whereas both $\beta$-actin and $\alpha$-tubulin are major axonal proteins transported by slow axonal transport mechanisms, only $\beta$-actin mRNA is selected and transported to the axonal domain.

The differential distribution of mRNAs encoding for specific cytoskeletal proteins that we report here for neurons has been demonstrated in other cell types. Recent studies have shown that myoblasts can select and target mRNA encoding the specific actin isoforms to their correct distinct sites: whereas the localization of $\alpha$ - and $\gamma$-actin mRNAs is restricted to the perinuclear region, $\beta$-actin mRNA is targeted and anchored to specific binding sites at the cell periphery (Hill and Gunning, 1993; Kislauskis et al., 1993). Similarly, peripheral neurons in our cultures possess the capacity to specifically select and target a subset of poly $\left(\mathrm{A}^{+}\right)$ mRNAs to the axonal domain that include mRNA encoding $\beta$-actin but not $\alpha$-tubulin. Because we obtained a bright hybridization signal in axons using oligo(dT) probes, but failed to detect $\beta$-actin mRNA consistently using specific probes (data not shown), we assume that the axonal mRNA population contains a variety of mRNAs. Analysis of axonal mRNA complexity is under investigation using other approaches.

\section{What is the role of axonal $m R N A$ ?}

Because axonal mRNAs are actively transported and specifically sorted, the presence of even small amounts of mRNA in distal axons seems likely to be physiologically significant. Although we lack direct evidence that mammalian axons carry out protein synthesis, local translation of these mRNAs in axons is an obvious hypothesis. However, it has been proposed recently that in magnocellular neurons axonal localization of specific mRNAs could serve to physically exclude them from the somatic trauslation machinery. Selected mRNAs, therefore, could be stored in axons in an untranslatable form and later, in response to specific stimuli, returned to the soma by retrograde transport and translated there (Mohr et al., 1993; Skutella et al., 1994). This hypothesis seems unlikely to explain the presence of mRNAs at the very distal portion of the axon. However, it is clear that different neurons may use axonal transport for different purposes depending on the cell type and the nature of encoded proteins. Whatever the function of axonal mRNA in any particular neuron, our data extend previous studies showing that mRNAs can be localized within axons and open the question of the mechanism of their transport.

\section{REFERENCES}

Ainger K, Avossa D, Morgan F, Hill SJ, Barry C, Barbarese E, Carson JH (1993) Transport and localization of exogenous myelin basic protein mRNA microinjected into oligodendrocytes. J Cell Biol 123:431-441.

Alberts B, Bray D, Lewis J, Raff M, Roberts K, Watson JD (1994) Molecular biology of the cell. London: Garland.

Baas PW, Ahmad FJ (1992) The plus ends of stable microtubules are the exclusive nucleating structures for microtubules in the axon. J Cell Biol 116:123I-1241.

Baas PW, Ahmad FJ (1993) The transport properties of axonal microtubules establish their polarity orientation. J Cell Biol 120:1427-1437.

Bassell GJ, Singer RH, Kosik KS (1994) Association of poly(A) mRNA with microtubules in cultured neurons. Neuron 12:571-582.

Berleth T, Burri M, Thomas G, Bopp D, Richstein S, Frigerio G, Noll M, Nusslein-Volhard C (1988) The role of localization of bicoid RNA in organizing the anterior pattern of the Drosophila embryo. EMBO J 7:1749-1756.

Black MM, Baas PW (1989) The basis of polarity in neurons. Trends Neurosci 12:211-214.

Black MM, Smith W (1988) Regional differentiation of the neuronal cytoskeleton with an appendix: diffusion of proteins in the neuron cell body - mathematical approximations and computer simulations. In: Intrinsic determinants of neuronal form and function (Lasek RJ, ed), pp 463-486. New York: Liss.

Brady ST (1991) Molecular motors in the nervous system. Neuron 7:521-533.

Bray D, Hollenbeck PJ (1987) Growth cone motility and guidance. Annu Rev Cell Biol 4:43-61.

Bruckenstein DA, Lein PJ, Higgins D, Fremeau Jr RT (1990) Distinct spatial localization of specific mRNAs in cultured neurons. Neuron 5:809 819.

Burgin KE, Waxham MN, Rickling S, Westgate SA, Mobley WC, Kelly PT (1990) In situ hybridization histochemistry of $\mathrm{Ca}^{2+} /$ calmodulindependent protein kinase in developing rat brain. J Neurosci 10:1788-1798.

Chomczynski P, Sacchi N (1987) Single-step method of RNA isolation by guanidium-thiocyanate-phenol-chloroform extraction. Anal Biochem 162:156-159.

Cleveland DW, Hoffman PN (1991) Slow axonal transport models come full circle: evidence that microtubule sliding mediates axon elongation and tubulin transport. Cell 67:453-456.

Cripe I, Morris F, Fulton AB (1993) Vimentin mRNA location changes during muscle development. Proc Natl Acad Sci USA 90:2724-2728.

Crispino M, Perrone Capano C, Kaplan BB, Giuditta A (1993a) Neurofilament proteins are synthesized in nerve endings from squid brain. J Neurochem 61:1144-1146.

Crispino M, Perrone Capano C, Martin R, Menichine E, Kaplan BB, Giuditta A (1993b) Protein synthesis in a synaptosomal fraction from squid brain. Mol Cell Neurosci 4:366-374.

Davis L, Dou P, DeWit M, Kater SB (1992) Protein synthesis within neuronal growth cones. J Neurosci 12:4867-4877.

Ding D, Lipshitz HD (1993) Localized RNAs and their functions. Bioessays 15:651-658.

Ehrlich ME, Grillo M, Joh TH, Margolis FL, Baker H (1990) Transneuronal regulation of gene expression in the mouse olfactory bulb. Mol Brain Res 7:115-122.

Elinson RP, King ML, Forristall C (1993) Isolated vegetal cortex from Xenopus oocytes selectively retains localized mRNAs. Dev Biol 160:554 562 .

Ephrussi A, Dickinson LK, Lehman R (1991) Oskar organizes the germ plasm and directs the localization of the posterior determinant nanos: Cell 66:37-50.

Fekete DM, Brockes JP (1987) A monoclonal antibody detects a difference in the cellular composition of developing and regenerating limbs of newts. Development 99:589-602.

Ferrandon D, Elphick L, Nüsslein-Volhard C, St. Johnston D (1994) Staufen protein associates with the $3^{\prime}$ UTR of bicoid mRNA to form particles that move in a microtubule-dependent manner. Cell 79:1221-1232. 
Fontaine B, Changcux JP (1989) Localization of nicotinic acctylcholine receptor alpha-subunit transcripts during myogenesis and motor endplate development in the chick. J Cell Biol 108:1025-1037.

Fontaine B, Sassoon D, Buckingham M, Changeux JP (1988) Detection of the nicotinic acetylcholine receptor alpha-subunit mRNA by in situ hybridization at neuromuscular junctions of 15-day-old chick striated muscles. EMBO J 7:603-609.

Forristall C, Pondel M, Chen LH, King ML (1995) Patterns of localization and cytoskeletal association of two vegetally localized RNAs, Vg1 and XCAT-2. Development 121:201-208.

Garner CC, Tucker RP, Matus A (1988) Selective localization of messenger RNA for cytoskeletal protein MAP2 in dendrites. Nature 336:674-677.

Gavis ER, Lehman R (1992) Localization of nanos RNA controls embryonic polarity. Cell 71:310-313.

Gioio AE, Chun J-T, Crispino M, Perrone Capano C, Giuditta A, Kaplan BB (1994) Kinesin mRNA is present in the squid giant axon. J Neurochem 63:13-18.

Giuditta A, Menichine E, Perrone Capano C, Langella M, Castigli E, Kaplan BB (1991) Active polysomes in the axoplasm of squid giant axon. J Neurosci Res 28:18-28.

Grafstein B, Forman DS (1980) Intracellular transport in neurons. Physiol Rev 60:1167-1283.

Heidemann SR, Buxbaum RE (1991) Growth cone motility. Curr Opin Neurobiol 1:339-345.

Hesketh JE, Pryme IF (1991) Interaction between mRNA, ribosomes and the cytoskeleton. Biochem J 277:1-10.

Hill MA, Gunning P (1993) Beta and gamma actin mRNAs are differentially located within myoblasts. J Cell Biol 122:825-832.

Hirokawa N (1993) Axonal transport and the cytoskeleton. Curr Opin Neurobiol 3:724-731.

Hollenbeck PJ (1993) Products of endocytosis and autophagy are retrieved from axons by regulated retrograde organelle transport. J Cell Biol 121:305-315

Hollenbeck PJ, Bray D (1987) Rapidly transported organelles containing membrane and cytoskeletal components: their relation to axonal growth. J Cell Biol 105:2827-2835.

Hoock TC, Newcomb PM, Herman IM (1991) $\beta$-Actin and its mRNA are localized at the plasma membrane and the regions of moving cytoplasm during the cellular response to injury. $\mathbf{J}$ Cell Biol 112:653-664.

Jirikowski GF, Sanna PP, Bloom FE (1990) mRNA coding for oxytocin is present in axons of the hypothalamo-neurohypophyseal tract. Proc Natl Acad Sci USA 87:7400-7404

Kaplan BB, Gioio AE, Perrone Capano C, Crispino M, Giuditta A (1992) Beta-actin and beta-tubulin are components of a heterogenous mRNA population present in squid giant axon. Mol Cell Neurosci 3:133-144.

Kelly RB, Grote E (1993) Protein targeting in the neuron. Annu Rev Neurosci 16:95-127.

Kilmartin JB, Wright B, Milstein C (1982) Rat monoclonal anti-tubulin antibodies derived by using a new nonsecreting rat cell line. $\mathrm{J}$ Cell Biol 93:576-582.

Kislauskis EH, Zhifang L, Singer RH, Taneja KL (1993) Isoform-specific 3 -untranslated sequences sort $\alpha$-cardiac and $\beta$-cytoplasmic messenger RNAs to different cytoplasmic compartments. J Cell Biol 123:165-172.

Kleiman R, Banker G, Steward O (1990) Differential subcellular localization of particular mRNAs in hippocampal neurons in culture. Neuron 5:821-830.

Kloc M, Etkin LD (1994) Delocalization of Vgl mRNA from the vegetal cortex in Xenopus oocytes after destruction of XIsirt RNA. Science 265:1101-1103.

Kloc M, Reddy BA, Miller M, Eastman E, Etkin LD (1991) x121: a localized maternal transcript in Xenopus laevis. Mol Reprod Dev 28:341-345.

Kost TA, Theodorakis $\mathrm{N}$, Hughes SH (1983) The nucleotide sequence of the chick $\beta$-actin gene. Nucleic Acids Res 11:8287-8301

Ku M, Melton DA (1993) Xwnt-11: a maternally expressed Xenopus wnt gene. Development 119:1161-1173.

Lamoureux P, Steel VL, Regal C, Adgate L, Buxbaum RE, Heidemann SR (1990) Extracellular matrix allows PC12 neurite elongation in the absence of microtubules. J Cell Biol 110:71-80.

Landry C, Crine P, Desgroseillers L (1992) Differential expression of neuropeptide gene mRNA within LUQ cells of Aplysia californica. J Neurobiol 23:89-101.
Lawrence JB, Singer RH (1986) Intracellular localization of messenger RNAs for cytoskeletal proteins. Cell 45:407-415.

Litman P, Barg J, Ginzburg I (1994) Microtubules are involved in the Iocalization of tau mRNA in primary neuronal cell cultures. Neuron 13:1463-1474.

Lyford GL, Yamagata K, Kaufmann WE, Barnes CA, Sanders LK, Copeland NG, Gilbert DJ, Jenkins NA, Lanahan AA, Worley PF (1995) Arc, a growth factor and activity-regulated gene, encodes a novel cytoskeleton-associated protein that is enriched in neuronal dendrites. Neuron 14:433-445.

Marsh L, Letourneau PC (1984) Growth of neurites without filopodial or lamellipodial activity in the presence of cytochalasin B. J Cell Biol 99:2041-2047.

Melton DA (1987) Translocation of a localized mRNA to the vegetal pole of Xenopus oocytes. Nature 328:80-82.

Merlie JP, Sanes JR (1985) Concentration of acetylcholine receptor mRNA in synaptic regions of adult muscle fibres. Nature 317:66-68.

Miyashiro K, Dichter M, Eberwine J (1994) On the nature and differential distribution of mRNAs in hippocampal neurites: implications for neuronal functioning. Proc Natl Acad Sci USA 91:10800-10804.

Mohr E, Richter D (1992) Diversity of mRNAs in the axonal compartment of peptidergic neurons in the rat. Eur J Neurosci 4:870-876.

Mohr E, Richter D (1993) Dendritic and axonal mRNA trafficking. Regul Pept 45:21-24.

Mohr F, Fehr S, Richter D (1991) Axonal transport of neuropeptide encoding mRNAs within the hypothalamo-hypophyseal tract of rats. EMBO J 10:2419-2424.

Mohr E, Zhou A, Thorn NA, Richter D (1993) Rats with physically disconnected hypothalamo-pituitary tracts no longer contain vasopressin-oxytocin gene transcripts in the posterior pituitary lobe. FEBS Lett 263:332-336.

Morris EJ, Fulton AB (1994) Rearrangement of mRNAs for costamere proteins during costamere development in cultured skeletal muscle from chicken. J Cell Sci 107:377-386.

Morris RL, Hollenbeck PJ (1993) The regulation of bidirectional mitochondrial transport is coordinated with axonal outgrowth. J Cell Sci $104: 917-927$

Morris RL, Hollenbeck PJ (1995) Axonal transport of mitochondria along microtubules and $\mathrm{F}$-actin in living vertebrate neurons. $\mathrm{J}$ Cell Biol 131:1315-1326.

Mosquera L, Forristall C, Zhou Y, King ML (1993) A mRNA localized to the vegetal cortex of Xenopus oocytes encodes a protein with a nanos-like zinc finger domain. Development 117:377-386.

Neuman-Silberberg F, Schubach T (1993) The Drosophila dorsoventral patterning gene gurken produces a dorsally localized RNA and encodes a TDGa-like protein. Cell 75:165-174.

Nixon RA (1991) Axonal transport of cytoskeletal proteins. In: The neuronal cytoskeleton (Burgoyne RD, ed), pp 283-307. New York Wiley-Liss.

Pachter JS (1992) Association of mRNA with the cytoskeletal framework: its role in the regulation of gene expression. Crit Rev Eukaryot Gene Expr 2:1-18.

Peng I, Binder LI, Black MM (1986) Biochemical and immunological analyses of cytoskeletal domains of neurons. J Cell Biol 102:252-262.

Perrone Capano C, Giuditta A, Castigli E, Kaplan BB (1987) Occurrence and sequence complexity of polyadenylated RNA in squid axoplasm. J Neurochem 49:698-704.

Peters A, Palay SL, Webster HD (1976) The fine structure of the nervous system: the neurons and supporting cells. Philadelphia: Saunders.

Pokrywka NJ, Stephenson EC (1995) Microtubules are a general component of mRNA localization systems in Drosophila oocytes. Dev Biol $167: 363-370$.

Rapallino MV, Cupcllo A, Giuditta A (1988) Axoplasmic RNA species synthesized in the isolated squid giant axon. Neurochem Res 13:625-631.

Ressler KJ, Sullivan SL, Buck LB (1994) Information coding in the olfactory system; evidence for a stereotyped and highly organized epitope map in the olfactory bulb. Cell 79:1245-1255.

Rings EH, Buller HA, Neele AM, Dekker J (1994) Protein sorting versus messenger RNA sorting? Eur J Cell Biol 63:161-171.

Rogers KE, Grillo M, Sydor W, Poonian M, Margolis FL (1985) Olfactory neuron-specific protein is translated from a large poly $(A+)$ mRNA Proc Natl Acad Sci USA 84:1704-1708. 
Skutella T, Probst JC, Blanco E, Jirikowski GF (1994) Localization of tyrosine hydroxylase mRNA in the axons of the hypothalamoneurohypophyseal system. Brain Res 23:179-184.

Sobue K (1993) Actin-based cytoskeleton in growth cone activity. Neurosci Res 18:91-102.

St. Johnston D (1995) The intracellular localization of messenger RNAs. Cell 81:161-170.

Steward O (1994) Dendrites as compartments for macromolecular synthesis. Proc Natl Acad Sci USA 91:10766-10768.

Steward O, Banker GA (1992) Getting the message from the gene to the synapse: sorting and intracellular transport of RNA in neurons. Trends Neurosci 15:180-186.

Sundell CL, Singer RH (1991) Requirement of microfilaments in sorting of actin messenger RNA. Science 253:1275-1277.

Suprenant KA (1993) Microtubules, ribosomes, and RNA: evidence for cytoplasmic localization and translational regulation. Cell Motil Cytoskeleton 25:1-9.

Taneja KL, Singer RH (1990) Detection and localization of actin mRNA isoforms in chicken muscle cells by in situ hybridization using biotinylated oligonucleotide probes. J Cell Biochem 44:241-252.

Tiedge H, Zhou A, Thorn NA, Brosius J (1993) Transport of BC1 RNA in hypothalamo-neurohypophyseal axons. J Neurosci 13:4214-4219.

Trembleau A, Morales M, Bloom FE (1994) Aggregation of vasopressin mRNA in a subset of axonal swellings of the median eminence and posterior pituitary: light and electron microscopic evidence. $J$ Neurosci $14: 39-53$.
Vale RD, Banker G, Hall ZW (1992) The neuronal cytoskeleton. In: An introduction to molecular neurobiology (Hall ZW, ed), pp 247-280. Sunderland, MA: Sinauer.

Valenzuela P, Quiroga M, Rutter WJ, Kirschner MW, Cleveland DW (1981) Nucleotide and amino acid sequences encoded by $\alpha$ - and $\beta$-tubulin mRNAs. Nature 289:650-655.

Vallee RB, Bloom GS (1991) Mechanisms of fast and slow axonal transport. Annu Rev Neurosci 14:59-92.

Van Minnen J (1994a) Axonal localization of neuropeptide-encoding mRNA in identified axons of the snail Lymnaea stignalis. Cell Tissue Res 276:155-161.

Van Minnen J (1994b) RNA in the axonal domain: a new dimension in neuronal functioning? Histochem J 26:377-391.

Vassar R, Chao SK, Sitcheran R, Nunez JM, Vosshall LB, Axel R (1994) Topographic organization of sensory projections to the olfactory bulb. Cell 79:981-991.

Wang C, Lehman R (1991) Nanos is the localized posterior determinant in Drosophila. Cell 66:637-647.

Wensley CH, Stone DM, Baker H, Kauer JS, Margolis FL, Chikaraishi DM (1995) Olfactory marker protein mRNA is found in axons of olfactory receptor neurons. J Neurosci 15:4827-4837.

Wilhelm JE, Vale RD (1993) RNA on the move: the mRNA localization pathway. J Cell Biol 123:269-274.

Yisraeli JK, Sokol S, Melton DA (1990) A two-step model for the localization of maternal mRNA in Xenopus oocytes: involvement of microtubules and microfilaments in the translocation and anchoring of $\mathrm{Vg} 1$ mRNA. Development 108:289-298. 